\title{
PENGARUH KEKERASAN FISIK TERHADAP PERILAKU DISIPLIN
}

\author{
ANAK \\ Yulianti \\ Sekolah Tinggi Agama Kristen Terpadu Pesat Salatiga \\ Email: Iyulyulianti1@gmail.com
}

\begin{abstract}
The purpose of this study was to determine the effect of physical vionce on children's disciplinery behavior which is expected to assist parents in educating and disciplining children with correct and non-violent parenting so as to reduce physical violence against children. The research carried out is literature research methods carried out by reading books and journals, using various sources and evildence from the results of research, books, or expert opinions, by only selecting evidence that is in accordance with their beliefs and hypotheses. The data source is secondary data, the reference source is in the form of a theoretical literature review from books and journals that discuss the effects of physical violence and disciplinery behavior of children.
\end{abstract}

Keywords: Rough Parenting, Discliplinery Behavior, and Children.

\begin{abstract}
Abstrak
Tujuan dari penelitian ini adalah untuk mengetahui pengaruh kekerasan fisik terhadap perilaku disiplin anak yang diharapkan dapat membantu orangtua dalam mendidik dan mendisiplinkan anak dengan pola pengasuhan yang benar dan tidak dengan kekerasan sehingga dapat mengurangi kekerasan fisik terhadap anak-anak. Penelitian yang dlakukan adalah penelitian literatur metode yang dilakukan dengan cara membaca buku, dan jurnal, menggunakan berbagai sumber dan bukti baik dari hasil penelitian, buku, ataupun pendapat ahli, dengan hanya memilih bukti yang sesuai dengan keyakinan atau hipotesisnya. Sumber datanya adalah data sekunder, sumber referensi berupa kajian pustaka yang bersifat teori yang berasal dari buku dan jurnal, yang membahas tentang pengaruh kekerasan fisik dan perilaku disiplin anak.
\end{abstract}

Kata Kunci: Pola Pengasuhan Kasar, Prilaku Disiplin, dan Anak.

\section{PENDAHULUAN}

Orangtua seringkali melakukan

kekerasan fisik terhadap anak mereka, karena menganggap kekerasan fisik kepada anak, anak menjadi pribadi yang disiplin.
Kedisiplinan pada anak-anak adalah memberikan pengertian akan mana yang baik dan yang buruk. Pendidikan disiplin perlu di tanamkan pada anak bahwa berbuat 
kesalahan tentu mengandung sejumlah konsekuensi, untuk itulah fungsi hukuman dalam pendidikan anak. ${ }^{1}$

Perihal ini sering terjadi, karena anak yang tidak mengikuti keinginan atau kemauan dari orangtua. Akibatnya, anak mengalami hal-hal yang bersifat fatal bahkan mengancam nyawa mereka sendiri. Orangtua seringkali melakukan kekerasan fisik, seperti cubitan dan pukulan kepada anak dengan alasan anak tidak mengikuti perintah mereka. Alasan lainnya, karena anak sedang bermain dan tidak mendengarkan perkataan mereka. Orangtua melakukan itu, karena menganggap jikalau mereka melakukan kekerasan, anak akan mendengarkan dan tidak mengulanginya lagi, dan beranggapan bahwa dengan memukul Itulah cara yang dilakukan oleh orangtua untuk mendisiplinkan anak, tetapi tindakan tersebut tidaklah benar dan tidak edukatif. Malahan, tindakan itu membuat anak merasa takut dan tidak berani untuk melawan.

Disiplin hanya akan dapat terwujud melalui pembinaan sejak dini, sejak usia muda, dimulai dari lingkungan keluarga, melalui pendidikan, dan tertanam sejak usia muda yang semakin lama semakin kuat

\footnotetext{
${ }^{1}$ Choirun Nisak Aulina, "Penanaman Disiplin Pada Anak Usia Dini” 2 (2013): 36-49.
}

dalam dirinya dengan bertambahnya usia. Melalui pembinaan disiplin akan membentuk sikap, perilaku seseorang. Sikap, perilaku seseorang tidak dibentuk dalam sekejap, semua itu diperlukan pembinaan, tempaan yang terus menerus-menerus sejak dini. Tempaan tidak hanya kekerasan atau berupa fisik, sebab bilamana disiplin itu ditegakan dengan kekerasan atau ancaman, disiplin itu sendiri akan hancur dan rusak. Dalam menegakan disiplin bukanlah ancaman atau kekerasan yang diutamakan, yang diperlukan adalah ketegasan. Ketegasan dan keteguhan dalam melaksanakan peraturan merupakan modal utama dan syarat mutlak untuk mewujudkan disiplin. ${ }^{2}$

Tindakan kekerasan fisik yang dilakukan orangtua memengaruhi perilaku disiplin anak, karena anak akan mengalami trauma, gangguan fisik dan mental. Anak akan tumbuh menjadi pribadi yang cepat emosi, karena asupan perlakuan orangtua yang pernah ia diterima . Akibatnya, anak tidak mudah mempercayai orang lain lagi. Selanjutnya, memungkinkan anak akan melakukan jenis tindakan kekerasan fisik pada anak lain atau orang lain, karena kecenderungan anak melakukan perihal

\footnotetext{
${ }^{2}$ Ahmad Susanto, Manajemen Peningkatan Kinerja Guru Konsep, Strategi, Dan Implementasinya (Pranada Media, 2016).
} 
buruk yang dilakukan kepadanya untuk melampiaskan kepada orang lain. Anak melampiaskan perihal yang diterimanya, karena mereka menganggap yang dilakukannya adalah hal yang benar dan baik dalam pembentukan dirinya.

Barker (1987:1) mendefinisikan kekerasan dalam buku yang berjudul "The Social Work Dictionary", kekerasan adalah perilaku tidak layak yang mengakibatkan kerugian atau bahaya secara fisik, psikologis, atau finansial, baik yang dialami individu maupun kelompok. Sedangkan istilah child abuse atau kadang-kadang child maltreatment adalah istilah yang biasa digunakan untuk menyebut kekerasan terhadap anak. Dalam Encyclopedia Article from Encarta mengartikan child abuse yaitu kekerasan terhadap anak perbuatan yang disengaja yang menimbulkan kerugian atau bahaya terhadap anak-anak secara fisik maupun emosional, (Richard J. Gelles, 2004:1). ${ }^{3}$

Orangtua seringkali melakukan kekerasan fisik terhadap anak mereka. Tindakan tersebut terjadi oleh pola pengasuhan yang sudah terjadi secara turuntemurun. Pengasuhan merupakan tugas orangtua kepada anak-anaknya. Pengasuhan

\footnotetext{
${ }^{3}$ Abu bu Huraerah, Kekerasan Terhadap Anak (Bandung: Nuansa Cendekia, 2012), hal. 44.
}

tidak dibentuk dan diarahkan oleh minat dan kebutuhan pribadi, dan perspektif budaya. Makna pengasuhan pada intinya terletak pada apa yang Allah rancang untuk dicapai dan diketahui oleh setiap manusia. ${ }^{4}$ Namun, umumnya orangtua tidak memahami pengasuhan yang benar terhadap anakanaknya, mereka melakukan pengasuhan yang benar menurut pandangan klasik mereka. Seringkali pengasuhan yang orangtua terapkan tidaklah sepenuhnya benar, karena orangtua telah diasuh dengan pola pengasuhan yang sama dari keluarga yang menerapkan pengasuhan yang buruk, yakni tindakan kekerasan fisik. Kemudian, kita tidak layak menyalahkan mereka yang mewarisi pola pengasuhan yang sama dari keluarga terdahulu, karena mereka juga termasuk korbannya.

Pengasuhan yang benar adalah melakukan kehendak Allah dalam kehidupan anak-anak. Orangtua mampu memulai pengasuhan itu dengan mengenalkan Alkitab yang mengajarkan untuk selalu rendah hati, memberikan gambaran bahwa anak-anak sebenarnya bukanlah milik kita, melainkan milik yang menciptakan-Nya. Anak-anak adalah milik Allah (Mazmur 127:3). Artinya, rencana Allah ialah menjadikan orangtua

\footnotetext{
${ }^{4}$ Paul David Tripp, Bijak Menjadi Orang Tua (Jakarta, n.d.), hal. 27.
} 
sebagai agen atau perantara-Nya supaya merawat kehidupan anak-anak. ${ }^{5}$ Pengasuhan yang benar adalah sesuai dengan kehendak Allah, bukan dasar pola pengasuhan turuntemurun yang klasik itu. Beberapa orangtua tidak memahami pola pengasuhan yang benar, karena kurangnya pemahaman mereka akan pola pengasuhan, pendidikan yang relatif kurang.

Sebagai orangtua bukanlah hal yang mudah, apalagi menerapkan pola pengasuhan yang benar, jikalau menerapkannya dalam keluarga terdahulu dengan pola pengasuhan yang tidak benar secara turun-temurun. Hal itu, tidak mudah lekas untuk diubah. Cuma usaha dan niatlah yang mengubahnya. Selain itu, orangtua seharusnya menjadi wakil Allah dalam mendidik dan mengasuh anak di rute yang benar, orangtua memiliki tanggung jawab untuk mengasuh anak menjadi pribadi yang lebih baik dan membimbingnya ke jalan yang benar serta mendidik mereka menjadi pribadi yang disiplin.

Penelitian ini bertujuan untuk memberikan pemahaman terhadap orangtua agar dapat melakukan pola pengasuhan yang baik dan benar untuk mendidik perilaku disiplin anak. Mendisiplinkan anak tidak

\footnotetext{
${ }^{5}$ Paul David Tripp, Bijak Menjadi Orang Tua (Jakarta, n.d.). hal. 12.
}

hanya dengan melakukan kekerasan, tetapi melakukan diskusi atau memberikan peraturan dalam keluarga untuk mencari konsekuensi ketika anak melanggar aturan yang telah disepakati bersama-sama, sehingga membuat anak bertanggung jawab atas aturan yang telah dibuat dalam keputusan yang telah disepakati bersama.

\section{METODE PENELITIAN}

Metode penelitian yang digunakan adalah metode penelitian kepustakaan, metode penelitian kepustakaan merupakan penelitian yang dilakukan dengan cara membaca buku, majalah, dan sumber data lainnya di dalam perpustakaan. "Penelitian kepustakaan dilakukan karena tidak memungkinkan untuk dilakukan dalam bentuk studi lapangan (field research) atau karena adanya keinginan pribadi dari peneliti untuk melakuan penelitian kepustakaan" (Hamzah, 2019:50-51). ${ }^{6}$

Dalam studi literatur, peneliti menggunakan berbagai sumber dan bukti baik dari hasil penelitian, buku, ataupun pendapat ahli. Dalam studi literatur, dikenal istilah cherry pick yang menggambarkan

\footnotetext{
${ }^{6}$ Trygu, Studi Literatur Problem Based Learning Untuk Masalah Motivasi Bagi Siswa Dalam Belajar Matetatika (Guepedia, 2020). hal. 26.
} 
proses seleksi literatur oleh penulis dengan hanya memilih bukti yang sesuai dengan keyakinan atau hipotesisnya. $^{7}$

Sedangkan sumber datanya adalah data sekunder, data sekunder menurut Mukhadis (2015:127) adalah kelompok sumber refrensi berupa kajian pustaka yang bersifat teori yang berasal dari buku, monograf, ensiklopedia, buku tahunan, surat kabar atau majalah. ${ }^{8}$

Jadi penelitian yang dilakukan oleh penulis adalah metode literatur yaitu metode yang dilakukan dengan cara membaca buku, majalah, dan sumber data lainnya, menggunakan berbagai sumber dan bukti baik dari hasil penelitian, buku, ataupun pendapat ahli, dengan hanya memilih bukti yang sesuai dengan keyakinan atau hipotesisnya, sumber datanya adalah data sekunder, sumber refrensi berupa kajian pustaka yang bersifat teori yang berasal dari buku, monograf, ensiklopedia, buku tahunan, surat kabar atau majalah.

\section{PEMBAHASAN DAN HASIL}

\section{Kekerasan Fisik}

Definisis kekerasan menurut Kamus Besar Bahasa Indonesia (1995) adalah perbuatan seseorang atau sekelompok orang yang menyebabkan cedera atau matinya orang lain atau menyebabkan kerusakan fisik atau barang orang lain, kekerasan juga berarti paksaan. $^{9}$

Abuse adalah kata yang bisa diterjemahkan menjadi kekerasan, penganiayaan, penyiksaan, atau perlakuan salah. $^{10}$

Sementara itu, Barker (1987:23) mendefinisikan kekerasan terhadap anak adalah tindakan yang melukai berulang-ulang secara fisik dan emosional terhadap anak yang ketergantungan, melalui desakan hasrat, hukuman badan yang tak terkendali, degradasi dan cemoohan permanen atau kekerasan seksual, biasanya dilakukan para orangtua atau pihak lain yang seharusnya merawat anak. ${ }^{11}$

Kasar itu sama dengan tegas, terbuka, disiplin, tegar, terus terang tanpa basa-basi

\footnotetext{
${ }^{9}$ Rita Ismail Noorkasiani, Heryati, Sosiologi Keperawatan (Jakarta: Dokter EGC, 2009). hal. 81.

${ }^{10}$ Abu Huraerah, Kekerasan Terhadap Anak (Bandung: Nuansa Cendekia, 2012). (Bandung: Nuansa Cendikia, 2012). hal. 44.

${ }^{11}$ Ibid. hal. 47.
} 
yang tentu saja konotasinya berbeda dengan pemahaman orang bukan Batak. ${ }^{12}$

Jadi, kekerasan adalah orang yang menyebabkan cedera atau matinya orang lain atau menyebabkan kerusakan fisik, berupa penyiksaan, melukai berulang-ulang. Hal ini sering kali terjadi karena orangtua tidak mengetahui perannya dalam mendidik anak untuk menjadi lebih disiplin, dan orang tua seringkali melakukan kekerasan karena banyak hal dan banyak faktor yang mempengaruhi adapun faktor-faktor yang mempengaruhi:

Faktor kekerasan fisik

1. Faktor Budaya, Heddy Shri AhimsaPutra dkk. (1999) di berbagai masyarakat umumnya ada hubungan yang secara natural asimetris antara anak dan orang dewasa adalah merupakan landasan bagi hubungan asimetris secara kultural antara kedua kategori tersebut. Menurut Lestari Basoeki (1999) di luar faktor budaya penyebab lain mengapa banyak terjadi penganiayaan anak dan pelantaran anak, diantaranya: pertama, orang tua dahulu dibesarkan dengan kekerasan cenderung meneruskan pendidikan tersebut kepada anakanaknya. Kedua, kehidupan yang penuh stress seperti terlalu padat kemiskinan, sering berkaitan dengan tingkah laku agresif, dan menyebabkan terjadinya penganiayaan fisik terhadap anak. Ketiga, isolasi sosial, tidak adanya dukungan yang cukup dari lingkungan sekitar, tekanan sosial akibat situasi krisis ekonomi, tidak berkerja dan masalah perumahan akan meningkatkan kerentanan keluarga yang akhirnya akan menjadi penganiayaan dan pelantaran anak.

2. Faktor Ekonomi, kemiskinan yang dihadapi sebuah keluarga sering kali membawa keluarga tersebut pada situasi kekecewaan yang pada gilirannya menimbulkan kekerasan.

3. Faktor Peceraian, peceraian dapat menimbulkan problematika kerumahtanggaan seperti persoalan pemeliharaan anak, pemberian kasih sayang, pemberian nafkah dan sebagainya.

4. Faktor Kelahiran Anak di Luar Nikah, kelahiran di luar nikah menimbulkan masalah diantara kedua orang tua anak.

\footnotetext{
${ }^{12}$ Djapiter Tinambunan, Orang Batak KasarMembangun Citra Dan Karakter (Jakarta: Elex Media Komputindo, 2013). hal. Viii
} 
5. Faktor Permasalahan Jiwa atau Psikologis, mereka senantiasa berada dalam situasi kecemasan (anxiety) dan tertekan akibat mengalami depresi atau stress. ${ }^{13}$

\section{Perilaku Disiplin}

Hasil Riset Dr. Robert Clinton, seorang profesor kepemimpinan senior menyimpulkan salah satu faktor yang menjadikan tokoh-tokoh pemimpin dalam Alkitab, adalah disiplin. Kita bisa membayangkan, orang yang tidak disiplin akan berprilaku malas. Banyak menyianyiakan waktu, mencari kesenangan yang tidak bermanfaat. ${ }^{14}$

Disiplin merupakan perilaku nilai yang bisa dilakukan secara paksa dan bisa dilakukan secara sukarela. ${ }^{15}$

Jadi, perilaku disiplin sangat diperlukan dalam mendidik anak-anak karena orang yang dapat melakukan disiplin adalah orang yang sangat bermanfaat bagi orangorang disekitarnya dan dapat menjadi contoh dan teladan bagi orang-orang disekitnya.

\footnotetext{
${ }^{13}$ Bagong Suyanto, Masalah Sosial Anak (Jakarta: PT Fajar Interpratama Mandiri, 2016). hal. 32-35.

14 Yayasan Pelayanan Media Anthiokia (YAPAMA), Tabloid Reformata 149 Maret 2012 (Yayasan YAPAMA, 2012). hal. 8.
}

Anak

Pada dasarnya anak adalah bukan orang dewasa dalam bentuk kecil, melainkan manusia yang oleh karena kondisinya belum mencapai taraf pertumbuhan dan perkembangan yang matang, maka segala sesuatunya berbeda dengan orang dewasa pada umumnya.

Berdasarkan Kamus Besar Bahasa Indonesia (KBBI), anak adalah keturunan kedua, sedangkan dalam konsideran UndangUndang Nomor 23 tahun 2002 tentang perlindungan anak, dikatakan bahwa anak adalah amanah dan Karunia Tuhan Yang Maha Esa, yang alam dirinya melekat harkat martabat sebagai manusia seutuhnya. ${ }^{16}$

Dari pengertian di atas, kesimpulannya anak adalah keturunan kedua, yang belum mencapai usia 20 tahun dan belum pernah menikah.

Anak seharusnya masih dalam bimbingan orang tua, disini pola pengasuhan orangtua sangat berperan penting dalam prilaku disiplin anak, dan sudah menjadi tanggung jawab orang tua dalam mendidik

\footnotetext{
15 Aulina, "Penanaman Disiplin Pada Anak Usia Dini." "Pedogogia: Jurnal Pendidikan 2 (1), 36-49, 2013.

${ }^{16}$ Santhos Wachjoe Prijambodo, Bunga Rampai Hukum Dan Filsafat Indonesia (Jogyakarta: Deepublish, 2019).
} 
anak menjadi seorang yang bertumbuh di dalam prilaku disiplin.

\section{KESIMPULAN}

Pola pengasuhan kasar sangat berpengaruh terhadap perilaku disiplin anak, karena pola pengasuhan kasar dapat membentuk karakter disiplin anak, karakter disiplin anak tidak dibentuk dalam sekejap tapi memerlukan waktu yang lama dan karakter akan terus dibentuk secara terus menerus hingga anak bertumbuh menjadi seorang yang dewasa nantinya. Pembentukan karakter disiplin anak bergantung pada pola pengasuhan orangtua dalam mendidik atau mendisiplinkan anak.

\section{DAFTAR PUSTAKA}

(YAPAMA), Yayasan Pelayanan Media Anthiokia. Tabloid Reformata 149

Maret 2012. Yayasan YAPAMA, 2012.

Aulina, Choirun Nisak. "Penanaman

Disiplin Pada Anak Usia Dini” 2 (2013): 36-49.

Barbara, Ns. Laksita. Systematic Review Dalam Kesehatan: Langkah Demi Langkah. Jogyakarta: Cv Budi Utama, 2020.
Huraerah, Abu. Kekerasan Terhadap Anak. Bandung: Nuansa Cendekia, 2012.

Noorkasiani, Heryati, Rita Ismail. Sosiologi Keperawatan. Jakarta: Dokter EGC, 2009.

Prijambodo, Santhos Wachjoe. Bunga Rampai Hukum Dan Filsafat Indonesia. Jogyakarta: Deepublish, 2019.

Susanto, Ahmad. Manajemen Peningkatan Kinerja Guru Konsep, Strategi, Dan Implementasinya. Pranada Media, 2016.

Suyanto, Bagong. Masalah Sosial Anak. Jakarta: PT Fajar Interpratama Mandiri, 2016.

Tinambunan, Djapiter. Orang Batak KasarMembangun Citra Dan Karakter. Jakarta: Elex Media Komputindo, 2013.

Tripp, Paul David. Bijak Menjadi Orang Tua. Jakarta, n.d.

Trygu. Studi Literatur Problem Based Learning Untuk Masalah Motivasi Bagi Siswa Dalam Belajar Matetatika. Guepedia, 2020. 